\title{
Scientific traditions of the Cracow Doctor's Association
}

\author{
Monika Zamachowska, Ryszard W. Gryglewski \\ Department of the History of Medicine, Jagiellonian University Medical College, Kraków, Poland
}

Correspondence to:

Prof. Richard W. Gryglewski, MD PhD, Katedra Historii Medycyny,

Uniwersytet Jagielloński, Collegium Medicum, ul. Kopernika 7,

31-034 Kraków, Poland,

phone: +4812422 2116 e-mail: ryszard.gryglewski@uj.edu.pl Received: November 16, 2016 Revision accepted: November 16, 2016 Published online:

December 22. 2016

Conflict of interest: none declared.

Pol Arch Med Wewn. 2016;

126 (12): 967-979

doi:10.20452/pamw.3757

Copyright by Medycyna Praktyczna Kraków 2016
Introduction The Cracow Doctors' Association (in Polish: Towarzystwo Lekarskie Krakowskie) came into being in 1866, soon after the community of Galicia gained unexpected privileges due to the political changes in the Austro-Hungarian Empire. Compared to the Russian Partition, where persecution of Poles dramatically escalated after the collapse of the January Uprising, in Galicia favorable reforms were implemented. Austria, which miraculously did not come apart as a result of the war with Prussia in 1866, decided to fight for favor of the nations making up its monarchy in order to unite them with the country and the ruling dynasty. A "Time of thaw" was coming. All positions of authority were held by Poles, and count Agenor Gołuchowski became the governor general of Galicia. Imperial dispositions gave us national autonomy and Polish language in schools, courts, and administrative offices. German remained the official language only in the post office, railway and police departments. Despite this, as time went by, anti-Polish behaviors and restrictions escalated, but the situation was mitigated by the tense relations between Russia and Austria and the need to secure the Poles' support in the case of war between the two powers. Kraków was one of the most important cities in Galicia, and as a matter of fact the center of Polish scientific, cultural, and social life. That is why Kraków was the place where Polish scientific-patriotic ideas were developed by members of different clubs and organizations.

Medical ideas and publications started to appear in 1816 in the newly created Cracow Science Association and its Medical Section. The Association began to publish its own periodical, Yearbook of Cracow Science Association, where members of particular sections could publish their dissertations and papers. Slowly, the medical subjects, difficult for laypeople to understand due to the specific content of their issues, started to attract a lot of interested physicians, who began to consider creating their own scientific organization. That is how, in 1866, the Cracow Doctors' Association came into existence. ${ }^{1,2}$

The assumption was that it would not compete with the Department of Natural Science and Medicine of the Cracow Science Association. During the departmental meetings, subjects concerning the theory of medical science were discussed, and during the Association meetings, medical practice problems were covered. That is why, at the beginning, many physicians, including world-famous doctors, took part in both organizations. ${ }^{3}$ Due to the fact that it is impossible to separate theory and practice in medicine, gradually, all medical issues were transferred to the newly established Association.

Doctor Aleksander Kremer (1813-1880) was the driving force in creating the Cracow Doctors' Association. He saw the absolute necessity of establishing an independent institution gathering physicians and engaged the help of several of his fellow physicians, who had been active in the Department of Natural Science and Medicine of the Cracow Science Association, in his activities. Those people decided to meet during the scientific sessions in their own, strictly medical group. The meetings took place in their private apartments. At the same time, they were working on a legal constitution for their new assembly. ${ }^{1,3,4} \mathrm{Af}-$ ter a year of preparations and arrangements, on December 18, 1866, the newly created Association had its first scientific session. The list of founding members was as follows: Aleksander Kremer (a forensic doctor) Jakób Blattejs (an independent physician), Błażej Bobrzyński (a practicing physician in St. Lazarus Hospital), Franciszek Bulikowski (a practicing physician in Holy Spirit Hospital), Józef Fałęcki (a former adjunct professor in the Department of Medicine at Jagiellonian University), Jan Gawlik (a former adjunct professor in the Department of Medicine at Jagiellonian University), Jan Harajewicz (a former practicing prison physician and a former director of hospitals in Kraków), Józef Doskowski (a former adjunct 
professor in the Department of Surgery of Jagiellonian University), Aleksander Kryda (an associate professor of forensic chemistry of Jagiellonian University), Henryk Rasp (an independent physician), Teofil Stępiński (a former adjunct professor in the Department of Gynecology at Jagiellonian University), Józef Oettinger (a historian of medicine, at that time a practicing physician of the Jewish Hospital), Maciej Leon Jakubowski (an associate professor of pediatrics of Jagiellonian University), Bolesław Serkowski (an adjunct professor in the Department of Medicine at Jagiellonian University), Władysław Ściborowski (a former practicing physician in the hospital in Wilanów), Józef Szewczyk (a former adjunct professor in the Department of Medicine at Jagiellonian University), Jonatan Warszauer (an independent physician), Józef Jaszczurowski (an adjunct professor in the Department of Surgery at Jagiellonian University), Adam Czyżewicz (an adjunct professor in the Department of Obstetrics at Jagiellonian University), Leon Blumenstok (a former adjunct professor in the Department of Ophthalmology, a forensic doctor), and Andrzej Głuszak (a former adjunct professor in the Department of Surgery at Jagiellonian University and an assistant physician in St. Lazarus Hospital). ${ }^{4}$

Due to the prevailing political situation, the Association had excellent prospects. Medical Associations arising on Polish lands were educational centers, which enabled the exchange of experiences and propagated Polish medical thought abroad. They were also involved in social activities, in this case in Galicia. Even its name, Cracow Doctors' Association, suggested its reluctance for centralization or domination, while at the same time it was open to physicians from all over Galicia. As a matter of fact, the members of the Association came not only from Kraków, but also from out-of-town. The opportunity to make professional contacts with specialists from the academic center attracted physicians from the provinces, who were very eager to take part in the activities of the Association. From the beginning of its existence, the Association expanded rapidly. At the turn of the century, it was mainly professors and adjunct professors of the Department of Medicine at Jagiellonian University who took part in the work of the Association; therefore, lectures were given at the highest scientific level. During the meetings, academics from the Department and common practitioners shared their experience while presenting interesting clinical cases, informing others about the newest discoveries in medicine, demonstrating their own enhanced operation methods, and displaying medical instruments and new drugs. This was the place where Mikulicz demonstrated his own surgical methods, Glinski talked about the discovery of symptoms connected with pituitary gland lesions, and Cybulski presented his discovery of catechol amines in the suprarenal vein. ${ }^{2,5}$ The most interesting papers were published in the form of extensive articles in Medical Review (in Polish: Przegląd Lekarski), which from the beginning was a part of the Association. The Association also had its own library. Although young physicians rarely gave lectures during the Association meetings, which was regretted by the professorial staff, they took part in the gatherings or expanded their knowledge about the newest medical discoveries, thanks to their subscription to Medical Review. ${ }^{6}$ Even though there were times when the meetings gathered several dozen physicians, there were also times when less than 10 people attended. That is why Medical Review performed a crucial role. Apart from the extensive scientific publications, very detailed and multispecialist discussions, which were the result of the demonstrations and lectures conducted, were printed in the periodical. The subject matter of the meetings concerned the whole of medicine of those days and was very diverse. ${ }^{5,7}$ There were some cases, however, when issues concerning one medical specialization overwhelmingly dominated the meetings for some period of time, and the questions raised were so specialized that they became incomprehensible for other members. For that and many others reasons, the Cracow Gynecological Association came into being in 1889, as an independent body from the Cracow Doctors' Association. ${ }^{8}$

Except for strictly scientific activity, which was a priority for the Association, it performed very important social functions centered around Galicia. Those activities were mostly realized by the work of the Commissions, which comprised of members of the Association who worked together to solve a specific medical problem. The results of the scientific works of these commissions had direct social effects. Generally, commissions could be divided into two types: permanent, working for longer periods of time, even for years, and temporary, nonpermanent, organized to solve one specific current problem. The Commission for rabies, chancroids on nipples of wet-nurses breast-feeding children from foundling homes, protective vaccinations against smallpox, are only a few examples of commissions of great significance. The biggest permanent commission was the Balneological Commission, which was active during the years 1877-1889. As a result of its scientific work, the national balneological industry was promoted and developed. The other permanent commissions worth mentioning are Hygienic, Industrial, Lexical and Legal-Medical. The Hygienic (Sanitary) Commission prepared opinions for the Sanitary Commission established at the City Council of Kraków. It gave opinions on the Kraków sewage system and school hygiene, as well as assessed the sanitary conditions of public buildings. The task of the Industrial Commission was to support the national medical and pharmaceutical industry. It had the right to issue certificates confirming the highest quality of products. The Legal-Medical Commission worked completely differently. Its main goal was scientific activity, that is, the exchange of experience and 
information among forensic doctors and, in addition, taking care of their interests in legal and financial matters. The result of the work conducted by the Lexical Commission was the completion of a supplement and two dictionaries of Latin-Polish medical terminology, which was a basis for the unification of Polish medical nomenclature. It was an issue of particular importance because the division of Poland between three partitioning countries resulted in significant language differences, especially noticeable in the professional nomenclature. . $9,10^{-10}$

Due to such large-scale activity, the lack of a place belonging to the Association quickly became an issue. During the first 20 years of the Association's existence, its meetings took place in the Cracow Science Association building (later Polish Academy of Sciences) at Sławkowska street, No. 17. Later on, whenever it was possible, the gatherings were organized in different facilities belonging to the Department of Medicine at Jagiellonian University. After 10 years of endeavors, in 1903, the Association received a building site from the city and the construction of its residence, the House of Cracow Doctors' Association, began in the same year. The building, which to this day is the seat of the Association, was designed by Ignacy Sowiński, and the interiors were designed by Stanisław Wyspiański, who was a friend of the Association president in those days, Julian Nowak. Nowak was so enchanted by Wyspiański's art that he persuaded his colleagues to let him be the artist responsible for the design and decoration of functional forms in the building. The opening ceremony of the House was held on March 2, 1905. Since that day the Association has added its own meeting hall, library, and reading room. In the building there were also a head office, Medical Chamber, and Physicians Self-help Society. Shortly, the Association House became not only the seat of the Association, but also a center of scientific, cultural and social life for physicians. Today it is considered one of the most outstanding art works of the modernist period called Young Poland. 1,11,12

Difficult period of the Association activity falling on the time before World War I turned out to be the big time, in spite of the obvious limitations resulting from the policies of partitioning countries. The extremely hard work undertaken by the Association members during the time of partition was an excellent preparation for the activity in the time of independence. During the interwar period, the activities of the Association concentrated on different areas. The social activity was not just pursuing the fight over the position of the Polish medical industry in the land of the foreign partitioning country, but it was promoting Poles in the international arena. The same went for science, which in the reborn Poland had a definite national character. ${ }^{13}$

A good example of scientific exchange between Polish scientists and a foreign country was Poland's cooperation with France. There was even a section called the French-Polish Medical Association, created within the framework of the Cracow Doctors' Association. Without a doubt, the great commitment of Polish scientists from the generation of French immigrants made things easier. It should be noted that Maria Skłodowska-Curie was the one who provided Polish university hospitals with radium for radiotherapeutic laboratories. In recognition of her outstanding scientific merits and mutual cooperation, she was awarded the courtesy title of honorary member of the Cracow Doctors' Association. During the interwar period, the number of members increased to 250 people and the weekly meetings repeatedly drew as many as 500 attendees. That is irrefutable proof of how high the level of scientific papers was. During this period, the subjects of the meetings concerned not only medicine, but also other sciences and even humanities. Unfortunately, at the same time the Association periodical, Medical Review, was lost. In 1921, due to financial issues, Medical Review was combined with the Lviv Weekly Medical Journal (in Polish: Lwowski Tygodnik Lekarski), creating the Polish Medical Periodical (in Polish: Polskie Czasopismo Lekarskie), and afterwards, in 1922, it became a part of the Polish Medical Journal (in Polish: Polska Gazeta Lekarska). Therefore, the reports from the meetings were published in the above-mentioned periodicals. They were also printed in Wiener Klinische Wochenschrift. ${ }^{13,14}$

This period of very intense activity of the Association during the time of independent Poland was interrupted by World War II. During the war, the Association suffered much regretted personal loss. Sadly, the Association House was also heavily damaged. In 1945, an explosion accompanying the blowing up of a nearby train bridge completely destroyed an enormous stained glass window featuring Apollo, created by Wyspiański to decorate the staircase. The exterior of the building was severely damaged as well. Despite that, the first meeting after liberation took place in April 1945, and the ongoing problems with the meeting venue did not interfere with weekly Wednesday gatherings of the members. The tradition of Wednesday meetings is maintained until this day. $1,5,11,12,14$

In the times of the Polish People's Republic, the Association succeeded in publishing the Medical Review once again. However, the Association House building was not regained. Initially, it was a storehouse, then a military college and library of the Medical Academy. During that period, the building fell into ever greater disrepair. The historic equipment decayed and the original decorations were painted over. Upon detection of the first noticeable dangerous cracks in the construction and deflection of its walls and roof in 1972, temporary maintenance works were conducted, and the foundation of the Cracow Doctors' Association managed to organize the reconstruction of the stained glass window. One year later, remnants of historical furniture were included in the conservation, and during the years 
FIGURE 1

Prof. Alfred Biesiadecki. Photo by Awit Szubert. Kraków, 1870s. Source: Department of the History of Medicine, Jagiellonian University Medical College, Kraków, Poland

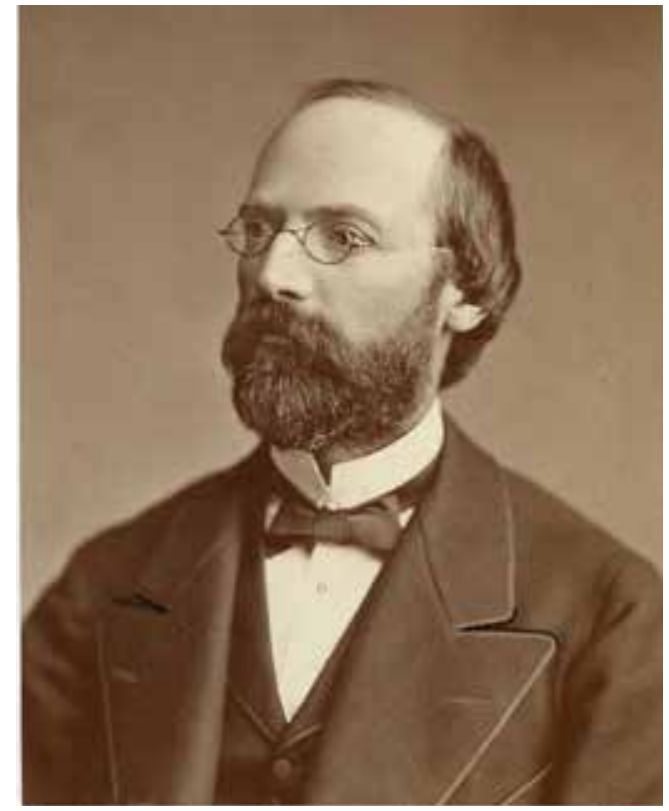

from 1980 to 1982, complex modernization works were conducted, restoring the original value of this modernist work of art. Not until 1991 did the Association regain the whole of its building at Radziwiłłowska street, No. 4. In spite of all the adversities and "soviet care", the level of scientific papers was still high and the contacts with representatives of Western medicine were still strong, even though, out of necessity, events like The Week of Polish-Soviet Medicine were organized. In Kraków, the popularization of soviet science was mainly focused on Pavlov's achievements. ${ }^{11,14}$ In 1951, at the request of the Scientific Board of the Minister of Health, the Polish Medical Association came into being and the Cracow Doctors' Association became its department. The Association functions on the same basis today. To sum up the period of the Polish People's Republic, we can say that the most important achievements of this time were the development of the Medical Code of Ethics and Deontology in 1967 and publication of 31 special numbers of Medical Review - Oświęcim Notebooks (in Polish: Zeszyty Oświęcimskie), which were nominated for Nobel Peace Prizes twice, in 1994 and 1995. ${ }^{14}$ Since the Association returned to its House and began independent activity in the Third Polish Republic, the main goal of the Cracow Doctors' Association has been the organization of scientific and training meetings, and the integration of Doctors. Currently, the Association emphasizes the popularization of humanistic aspects of medicine. ${ }^{15}$ Many prominent physicians, who with their achievements contributed to the development of Polish, European, and even global medicine, were active in the Association. There is no way to mention all of them in a short article. However, the profiles of several scientists are worth mentioning since their accomplishments made them world-famous.

Alfred Biesiadecki (1839-1889), the president of the Cracow Doctors' Association in 1870 Alfred
Biesiadecki (FIGURE 1) studied medicine at the University of Vienna. In 1862, he was awarded the degree of doctor of medicine and surgery, and a year later a master's degree in obstetrics. In 1865 , the scientist became an assistant in the Institute of Pathological Anatomy in Vienna, managed by world-famous scientist, professor Karl von Rokitansky. When Biesiadecki was only 29, he was awarded the degree of professor and took charge of the Department of Pathological Anatomy at Jagiellonian University, which he managed for 8 years. Thereafter, he left Kraków and accepted the high-level position of Protomedicus (supreme medic) of Galicia, with his seat in Lviv. He died in 1889. ${ }^{16-18}$

Biesiadecki is considered one of the pioneers of modern research on pathological skin changes and thus, a pioneer of modern dermatology. He learned its basics in Vienna between the years 1864 and 1865, while working in the Department of Skin Diseases at the Public Hospital under Ferdinand von Hebra. With his practice in the microscopic laboratory (professor Karl Wedl) and the microscopic dermatology laboratory (professor Ernst von Brücke), Biesiadecki initiated long-term research, de facto becoming one of the first skin histopathologists in the world. The most significant of Biesiadecki's research achievements are the correct classification and explanation of the formation mechanism of sebaceous gland disorders and the phenomenon of seborrhea in the course of skin diseases. At that time, he also announced an exact histological description of a comedo. Biesiadecki was the first to conduct the competent division, together with classification of histopathological changes associated with different types of acne. He complemented former observations and compiled features of skin inflammatory process in a coherent whole. The researcher also isolated a microscopic image of infection focus and proved the essential role of the blood vessel system and blood itself in this process. His descriptions of the observations and the conclusions he drew were accompanied by precise figures, which were used in the studies canonical for dermatology of those days: Fredinand von Hebra's Medizinische Lehrbücher and Moritz Kaposi's Pathologie und Therapie der Hautkrankheiten. A monograph summarizing the knowledge of the histology of skin, hair, and nails Haut, Haare und Nagel as a whole became a part of the study Handbuch der Lehre von den Geweben des Menschen und der Thiere (Leipzig 1871) edited by Salomon Stricker, which was subsequently frequently used. ${ }^{17,19}$

Tadeusz Browicz (1847-1928), an honorary member of The Cracow Doctor's Association Tadeusz Browicz (FIGURE 2) earned his degree in medical studies at Jagiellonian University. In 1872, the scientist was awarded the degree of doctor of medical sciences. During his studies, he was already associated with the Institute of Pathological Anatomy of Jagiellonian University, where later he became 
FIGURE 2

Prof. Tadeusz Browicz, c. 1900 . Photo: Siebald Kraków. Source:

Department of the History of Medicine, Jagiellonian University Medical College, Kraków, Poland

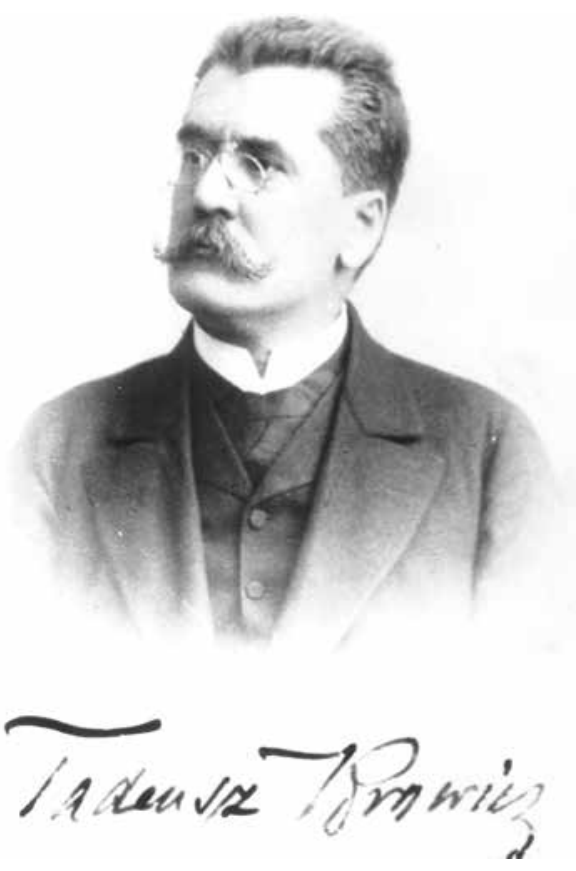

FIGURE 3

Prof. Edward Korczyński, c. 1900. Heliogravure J. Löwy, Wien. Source: Department of the History of Medicine, Jagiellonian University Medical College, Kraków, Poland from the culture. Six years later, the same discovery was made by a German pathologist, Karl Eberth, who apparently was not aware of his predecessor's findings and documented his research in detail. The German scholar also did not succeed in obtaining a pure colony of typhoid fever bacteria. The person who accomplished that was Georg Gaffky in $1884{ }^{22}$

Independently from the German scientist, Karl Kupffer, Browicz described a new type of cells in liver blood vessels, which, as we know today, are a significant part of the mononuclear phagocyte system. Kupffer, who called them "star cells", considered them an integral part of endothelium of the liver blood vessels. Browicz indicated that, as a matter of fact, they are not in any way permanently integrated with the wall of blood vessel and emphasized their phagocytic character. That is why the name Kupffer-Browicz cells, sometimes used in the source literature, seems to be more adequate because it is consistent with the research history. ${ }^{22,23,24}$

Edward Korczyński (1844-1905), the president of the Cracow Doctors' Association in 1875-1876 Edward Korczyński (FIgURE 3) studied medicine in the years 1862-1867 at the Department of Medicine at Jagiellonian University. In 1868, the scientist was awarded the degree of doctor, and soon after a master of obstetrics and doctor of surgery. From 1869, he worked as an assistant in the Department of Internal Medicine at Jagiellonian University. In 1872, he was made the head of St. Lazarus Hospital in Kraków. Two years later, he became a professor and took lead of the Department of Internal Diseases at Jagiellonian University. He died in 1905. ${ }^{25,26}$

Korczyński was a creator of the modern medical university hospital, in which the first medical specializations were separated: cardiology and gastroenterology.

In 1878, an Austrian physician, Adam Hammer, properly diagnosed symptoms of coronary artery embolism in the heart, which was later confirmed in a post-mortem examination. In 1887, Korczyński also made a diagnosis of a living patient with heart coronary artery embolism, and it was confirmed during an autopsy. We can assume that this description of clinical signs of a heart attack caused by an embolism was the second one in the world. However, Korczyński’s description was more complete and better organized. ${ }^{27,28}$

Jan Mikulicz-Radecki (1850-1905), the president of the Cracow Doctors' Association in 1887 Jan Mikulicz-Radecki (FIgURE 4) completed his medical studies in Vienna during the years of 1869-1875 and he was awarded the degree of doctor of medical sciences. First he was a student and then an assistant in the surgical department of professor Theodor Billroth. In 1880, Mikulicz received veniam legendi in surgery. In 1882, the scientist was awarded the degree of professor and took lead in the Department of Surgery at Jagiellonian 
FIGURE 4 Prof. Jan

Mikulicz-Radecki, c. 1883. Source:

Department of the History of Medicine, Jagiellonian University Medical College, Kraków, Poland

FIGURE 5 Prof. Antoni W. Gluziński, c. 1895.

Copy of original photo. Source: Department of the History of Medicine, Jagiellonian University Medical College, Kraków, Poland
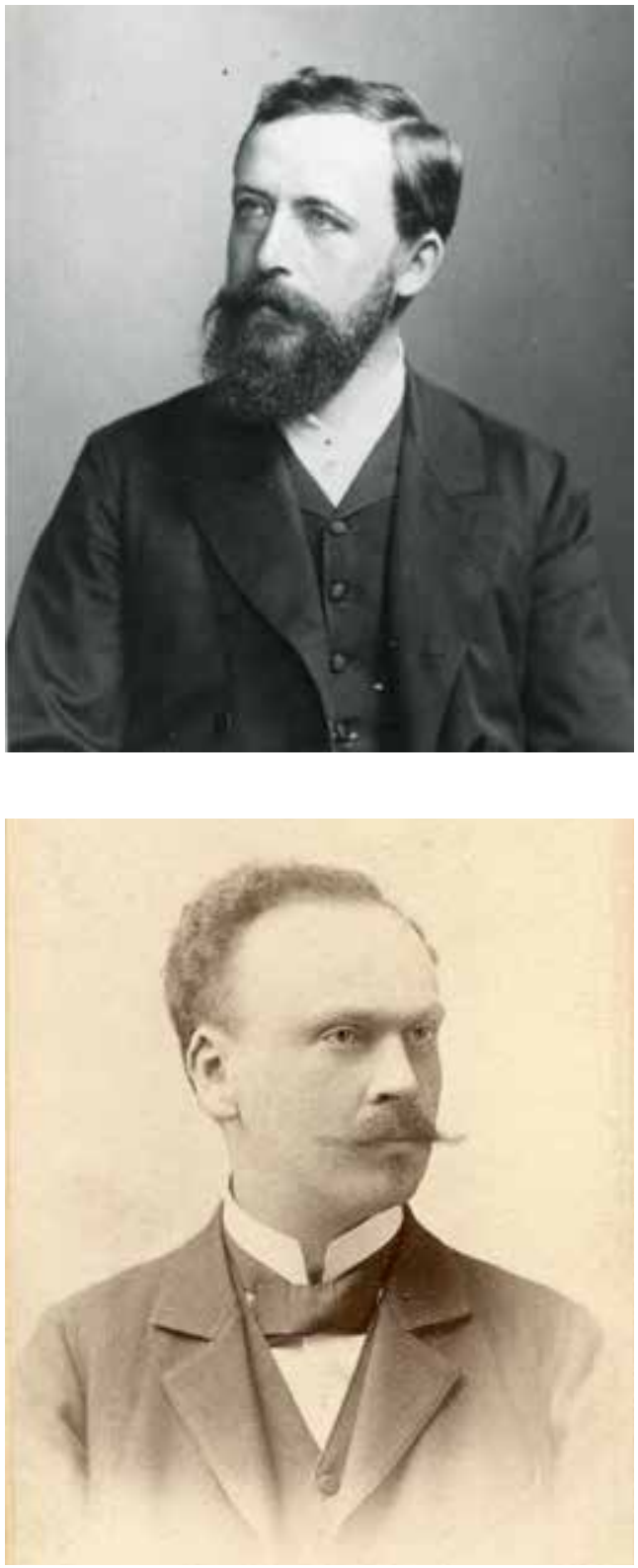

University. In 1880, he accepted the position of the head of university department in Królewiec (Kaliningrad). In 1897, he took lead of the Department of Surgery at Wrocław University, where he spent the last 15 years of life. ${ }^{29}$

Mikulicz was one of the world's pioneers of endoscopy and thoracic surgery. He performed surgeries of the digestive system, especially the stomach, which were significant on a global scale. He had a great input in gynecological surgery, laryngology, orthopedics, and genitourinary system surgery. His name should also be mentioned when speaking about the history of the development of modern asepsis and antiseptics.

Mikulicz was the first person in the world to perform a surgery of suturing a ruptured stomach ulcer (1885). He was also the first to develop the innovative method of plasty of pylorus (1887), which today is called Heineke-Mikulicz pyloroplasty. He modified and improved the procedure of two-stage colonic carcinoma resection with colostomy, which today is called the Paul-Mikulicz procedure. He developed the original method of vaginal total hysterectomy. Independently from Alexander Vladimirov, he proposed a method of osteoplastic resection of the foot, called Vladimirov-Mikulicz amputation. He was the first to perform a wedge resection of the thyroid gland. ${ }^{29}$

After several years of research, in 1881, Mikulicz, while cooperating with Joseph Leiter, designed a firm gastroscope equipped with electric light system, which was applied in medicine. Prior attempts at endoscopy of the esophagus and digestive tract (ia, Adolph Kussmaul, Gustav Trouvé, Louis Waldenburg) did not lead to the invention of a device which could be applied on humans. Mikulicz's construction was a breakthrough, which is why Mikulicz's gastroscope is considered to be the beginning of the world of endoscopy. ${ }^{30}$

During the last years of life, Mikulicz was engaged in thoracic surgery. He inspired experimental works leading to the creation of a vacuum chamber suitable for overcoming the problem of emphysema. The one who succeeded in solving this problem during the years of 1903-1905 was Ferdinand Sauerbruch, Mikulicz's assistant of those days in the department in Wrocław. In March 1904, after a series of experiments on animals, the first vacuum chamber for performing operations on patients was installed. In the exact same chamber, Mikulicz and Sauerbruch performed the first operation on an open chest in the world. At this time, other scientists, Ludwik Brauer and Walther Petersen, experimented on animals with the application of an endotracheal intubation. The world had to wait for the intubation of the first patient during an open chest procedure. However, the second method, as it was more convenient, cheaper, and easier, became the basis for modern thoracic surgery. ${ }^{31,32}$

Antoni Władysław Gluziński (1856-1935), the president of the Cracow Doctors' Association in 1891 Antoni W. Gluziński (FIGURE 5) studied medicine at the Department of Medicine at Jagiellonian University during the years of $1874-1880$ and was awarded the degree of doctor of medical sciences. The scientist completed his complementary studies at universities in Tartu, Vienna, Prague, Wrocław, Leipzig, Berlin, and Paris. He was an assistant, and from 1885, an associate professor in the Department of Internal Diseases at Jagiellonian University. In 1897, he became a professor and the head of the Department of Internal Diseases at Lviv University. In the years 1919-1927, he was the head of the 2nd Department of Internal Diseases at Warsaw University. When Gluziński retired in 1927, he became an honorary professor of Warsaw University and performed this function until his death in 1935. ${ }^{33,34,35}$

His main scientific interests included issues of gastroenterology, hematology, pulmonology, circulatory system pathophysiology, as well as early diagnostics of neoplastic diseases of the digestive tract. In 1887, together with Walery Jaworski, 
FIGURE 6

Prof. Kazimierz

Kostanecki, c. 1930.

Source: Department of the History of Medicine, Jagiellonian University Medical College, Kraków, Poland

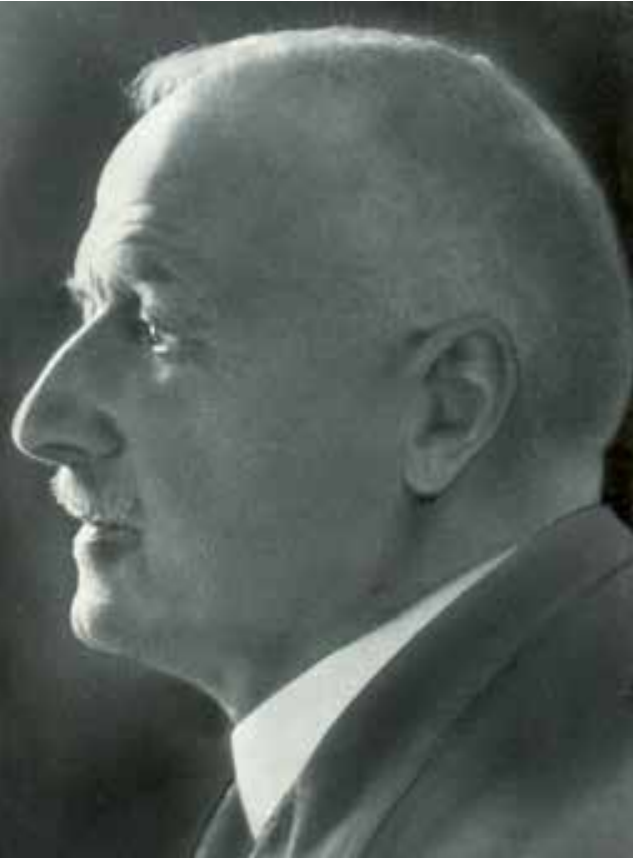

FIGURE 7 Prof. Julian Nowak, c. 1925. Copy of original photo. Source: Department of the History of Medicine, Jagiellonian University Medical College, Kraków, Poland

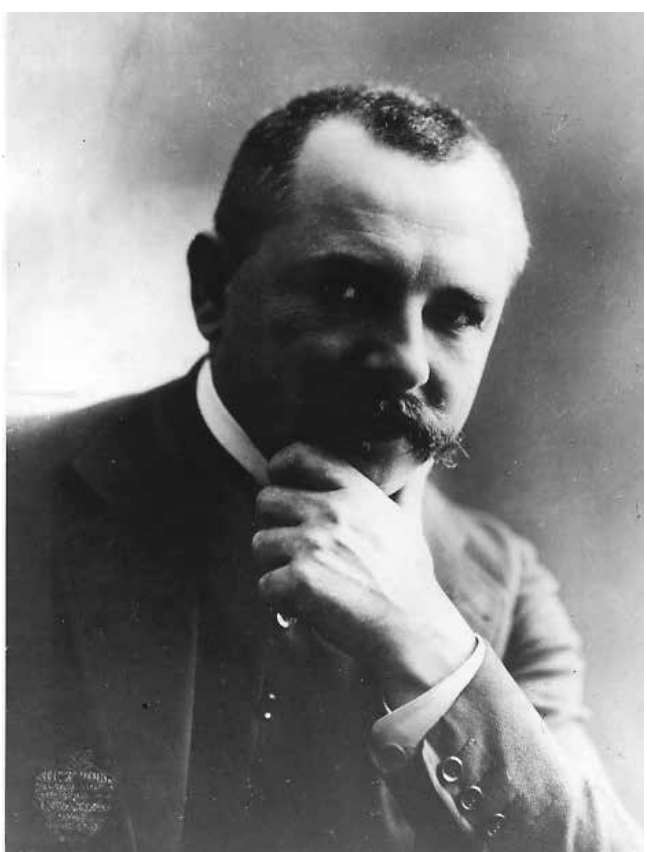

Gluziński determined the right values for stomach acidity. At the same time, they managed to prove that, from a physiological point of view, the essential process of digestion takes place in the small intestine. Consequently, they brought forward an innovative proposition that the classification of stomach diseases should be based not only on the gastric juice quantity disorder but also on its quality. ${ }^{33,34,36}$

In 1906, Gluziński published results of research on plasma cell leukemia conducted together with Mark Reichenstein. In their study, they presented the full clinical picture of this disease for the first time. They also separated characteristic mononuclear cells from the blood of sick patients. They called them plasma cells. They also proved that in the early stage of disease the plasma cells are not numerous and their number grows reaching, in terminal stage, as much as $77 \%$ of all blood circulating leukocytes. ${ }^{34,37}$

Kazimierz Kostanecki (1863-1940), the president of the Cracow Doctors' Association in 1901-1902 During the years of 1885-1890, Kazimierz Kostanecki (FIgUre 6) studied in Berlin. His mentors were Rudolf Virchow, Hermann von Helmholz, and Emil Du-Bois Reymond. Beginning in 1889, the scientist was an assistant in the Department of Anatomy in Berlin. In 1890, he was awarded the degree of doctor of medicine and surgery at this university. Finally, in the years 1891-1892, the researcher completed his complementary studies in Giessen. During the years 1892-1894, he was a professor and the head of the Department of Comparative Anatomy at Jagiellonian University. During the years 1894-1935, he was the head of the Department of Descriptive Anatomy at Jagiellonian University. Seriously ill, he died in horrible conditions of the German concentration camp Sachsenhausen. ${ }^{38-40}$

Kostanecki's scientific interests were very wide, including comparative, morphological, topographical, and developmental anatomy of different animal species and humans, as well as embryology and cytology. At the beginning, during his Berlin studies, he concentrated on the research on muscles and fasciae connected with the Eustachian tube. The scientist revised and completed a series of opinions concerning this issue. In this way, he presented a final and complete description of those structures. ${ }^{39,41}$ Kostanecki also conducted long-term and multidirectional comparative and experimental research on the mechanics of impregnation and early development phases of invertebrates. He was one of the pioneers of artificially induced parthenogenesis. ${ }^{42,43} \mathrm{He}$ developed and applied a globally innovative method of investigating and describing the process variation taking place during the parentogenetic development of mollusk eggs. Kostanecki was the first to present strong evidence for the appearance of the cecum on the border of midgut and hindgut in some species of reptiles and osteichthyes. He showed the developmental differences and changes in the range of cecum and appendix functions in many animal species. ${ }^{44}$

Julian Nowak (1865-1946), the president of the Cracow Doctors' Association in 1903-1905 Julian Nowak (FIGURE 7) completed his studies at Jagiellonian University (1886-1893) and was awarded the degree of doctor of medical sciences. Soon, he became an assistant at the Institute of Pathological Anatomy of Jagiellonian University. In 1899 , he completed his complementary studies at the University of Veterinary Medicine in Vienna. After graduation, he became an assistant professor of veterinary medicine and took lead of this unit at the Department of Medicine at Jagiellonian University. In 1906, Nowak was awarded the degree of full professor. He was the head of the Department of Veterinary Medicine, and Institute 
FIGURE 8

Prof. Napoleon N.

Cybulski, c. 1895.

Source: Department of the History of Medicine, Jagiellonian University Medical College, Kraków, Poland the 1st volume in 1927 and the second in 1930. In the atlas, Mycoplasma peripneumoniae is described in the 2nd volume titles "Fungi and protozoans". The research methods he had at his disposal did not allow unambiguous classification of the pathogen as bacteria. ${ }^{46}$

Napoleon Nikodem Cybulski (1854-1919), the president of the Cracow Doctors' Association in $1911 \mathrm{Na}$ poleon N. Cybulski (Figure 8) completed his studies at the Military Medical Academy in Saint Petersburg. He presented his doctoral thesis there in 1885. He was Professor Tarkhanov's assistant at the Department of Physiology. In the years 1885-1919, Cybulski was the head of the Department of Physiology at Jagiellonian University. ${ }^{47}$

His research achievements are predominated by work dedicated to blood physiology, digestion physiology, muscle physiology, neurophysiology, and experimental endocrinology.

In 1894, Cybulski, together with his assistant Władysław Szymonowicz, during experimental procedures on animals indicated, independently from British scientists George Oliver and Edward Schafer, that adrenal glands produced a biologically active substance, which was transferred by blood and had a systemic effect on the body. The Polish scientists called it suprarenin and proved its close connection with blood pressure, obtaining hypertension in a dog, with previously removed adrenal glands, after an intravenous injection of adrenal gland extract. At the same time, they noted a distinct bradycardia with a simultaneous increase of the number of breaths. Cybulski and Szymonowicz also stated that blood, drawn from a suprarenal vein of one dog, when injected into another dog also caused an increase in blood pressure, although in a visibly lower degree than in the case of extracts. In order to make sure that his assumptions were correct, Cybulski repeated his experiment with the blood collected from other veins and observed that the distinct hypertensive effect was produced only by the suprarenal blood. Today we know that under the name of suprarenin the discovery of catecholamine was concealed. According to available data, we can assume that at the beginning the Polish and the British scientists were not aware that they were working on the same problem. The first information from Oliver and Schafer came out in March 1894, the second in the same month of the next year. The first information from $\mathrm{Cy}$ bulski and Szymonowicz is dated March 1895. ${ }^{47-50}$

Cybulski also conducted research, pioneering on a global scale, on the mechanism of swallowing and the physiology of the sense of taste. He was the first to explain the phenomenon of the so called swallowing wave. The researcher inspired and supervised the work of his assistant, Adolf Beck, on the phenomenon of potential oscillation in the cerebral cortex. Thus, we should take his name into consideration when talking about the beginnings of brain neurophysiology. ${ }^{47}$ 
FIGURE 9

Prof. Bronisław Kader, c. 1911. Reproduction from original photo. Source: Department of the History of Medicine, Jagiellonian University Medical College, Kraków, Poland

FIGURE 10 Prof. Jan Piltz, c. 1910. Source: Department of the History of Medicine, Jagiellonian University Medical College, Kraków, Poland

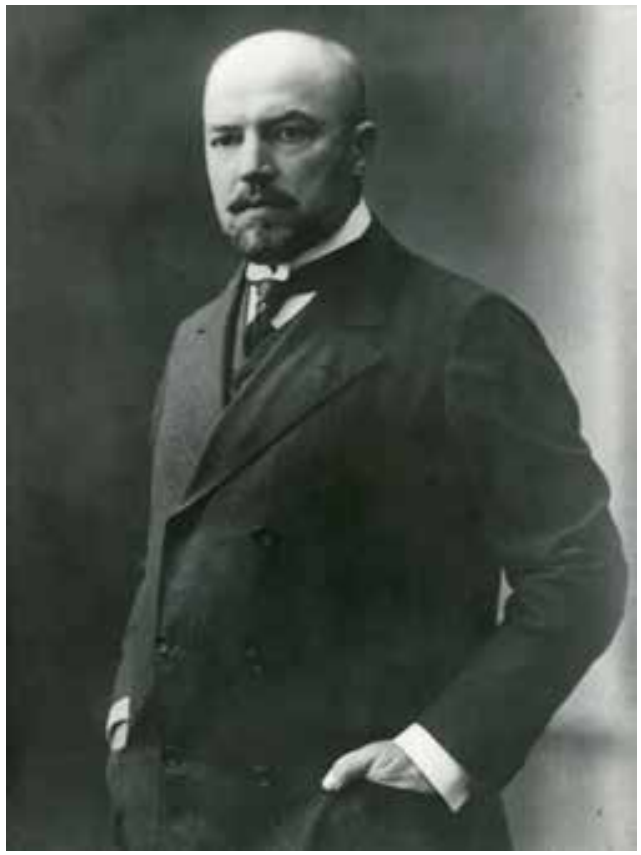

experiments were used by Kader to formulate the final conclusions, which were presented in his doctoral thesis under Wahl's supervision. ${ }^{53}$

Kader was an author of an important, and later commonly used, modification of the technique of gastric fistula insertion, whose completed rules were published in 1896. The main advantage of the presented technique was a relative noninvasiveness for those times. It required a small incision of the stomach's front wall to create a tunnel surrounded by serosa, next a drainage tube had to be inserted in the tunnel. Such a procedure ensured suitable conditions for healing of the fistula wound when the tube was removed. Next to the previously developed methods of Weitzl (1891) and Stamm (1894), Kader's modification became a part of surgical canon. And even though the development of endoscopic methods considerably limited its application, it was not completely excluded. ${ }^{52,54,55}$

Jan Piltz (1870-1930), the president of the Cracow Doctors' Association in 1917 During the years of 1888-1889, Jan Piltz (FIGURE 10) studied natural sciences and higher mathematics at the University of Zurich, and then medicine in Bern. He was awarded a medical diploma in 1895 . In the same year, he became an assistant in the psychiatric department managed by Auguste Forel. In 1897, Piltz left for St. Petersburg, and then moved to Kazan, where he validated his Swiss diploma. He came back to Switzerland in 1898. In 1901, he came to Warsaw where he worked as a clinician. In 1904, he obtained his doctoral degree at the University of Lausanne. A year later, Piltz became a professor of neurology and psychiatry at Jagiellonian University. From that moment until his death, he was the head of the department in Kraków. ${ }^{56-59}$

In his interests, Piltz combined neurological and psychiatric issues. His research on pupillary light reflexes should be considered significant and often enough critical. In 1899, at the same time as Alexandr Carl Westphal, Piltz described a phenomenon of the constriction of the pupil in the case of voluntary contraction of the muscle responsible for eyelid closure (orbicularis oculi muscle). It is still known under the name of Westphal-Piltz neurotonic pupillary reaction. ${ }^{60,61}$ Another reflex which was under Piltz's research is an attention reflex, for the very first time described by Swiss ophthalmologist Otto Haab. Its mechanism manifests itself as a contraction of the pupils without alteration of the eye's position. It was observed that when a patient sits in a darkened room and his or her attention is directed to a source of light placed to one side of him, then the contraction of the pupils is visible, even though the eyes are not being turned toward the light source. Piltz confirmed Haab's observations in several experiments with dark and light objects, for the first time giving evidence that the very same phenomenon manifests itself when tested on blind individuals. Today it is 
FIGURE 11

Prof. Aleksander Rosner c. 1920. Roproduction of original photo by $\mathrm{E}$. Węglowski. Source: Department of the History of Medicine, Jagiellonian University Medical College, Kraków, Poland

\section{FIGURE 12}

Prof. Adolf Beck

Source: https://

commons.wikimedia.org/ wiki/File:Adolf_Beck.jpg

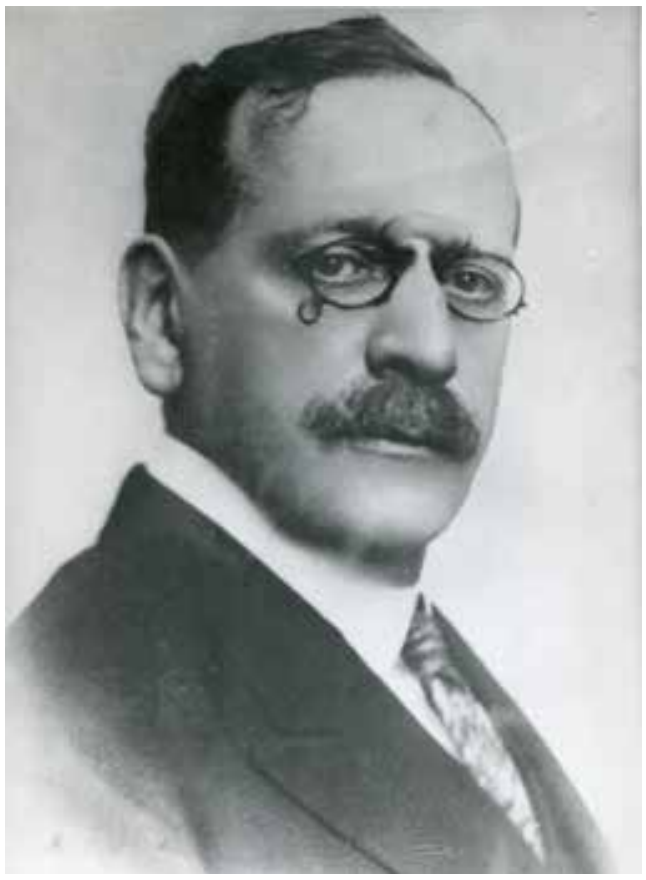

the degree of professor and took lead of the Department of Gynecological Obstetrics. He died suddenly on January $6,1930 .{ }^{62}$

Rosner conducted research on the etiology of malignant neoplasms. He was interested in gynecological surgery and introduced new operational techniques. The researcher was the first person in Poland to conduct the Wertheim procedure and developed his own method of ureter dissection during this operation. He was involved in radiotherapy of reproductive organs. ${ }^{63}$ Rosner also investigated the influence of metabolic disorders (especially obesity) on the functions of female reproductive organs and fertility. He studied the etiology of monochorionic twin pregnancy, conducting research on Brazilian armadillos. He carried out extensive research on the pathology of pregnancy, where he investigated the problem of eclampsia and hyperemesis gravidarum, among others. Rosner conducted very interesting colorimetric research which, on the basis of pregnant women's pigmentation, ought to indicate the group of patients threatened by eclampsia. Rosner's research, original on a global scale, concerned the theory of female sex organ constitution. The results were presented in the years 1918-1920. ${ }^{64,65}$ The constitution was understood as a genetic conditioning set of organ characteristics distinctive for a given person, nonchangeable depending on the environment. Rosner's notion of constitution was different than the one proposed by Freud and was close to today's concept of phenotype, which is why Rosner distinguished three basic constitutional types of women. The constitution was supposed to decide the disposition to specific sicknesses. He proposed very interesting conclusions, namely, that cystic ovarian degeneration is connected with its function disorders, and hirsutism should be joined with fertility disorders. In his department, he initiated research concerning gynecological endocrinology.

Adolf Beck (1863-1942), an honorary member of the Cracow Doctors' Association from 1917 In the years 1883-1889, Adolf Beck (FIgure 12) completed his studies at the Department of Medicine at Jagiellonian University. In 1890, he was awarded the degree of doctor of medical sciences. During his studies in the years 1888-1892, he was an assistant at the Physiology Institute of Jagiellonian University, managed by professor Napoleon Cybulski. In 1894, Beck presented his habilitation in physiology at the Department of Medicine at Jagiellonian University. From 1895, and for the next 40 years, he was a physiology professor at the Department Medicine at Lviv University. On retirement, he was still academically active. In 1942, he probably committed suicide before being transported to the gas chambers of the German extermination camp in Bełżec. ${ }^{66,67}$

Beck's leading research areas were neurophysiology and electrophysiology, as well as blood circulation physiology and digestion physiology. His 
FIGURE 13 Prof. Jan

Miodoński. Source:

Department of the

History of Medicine,

Jagiellonian University

Medical College, Kraków, Poland

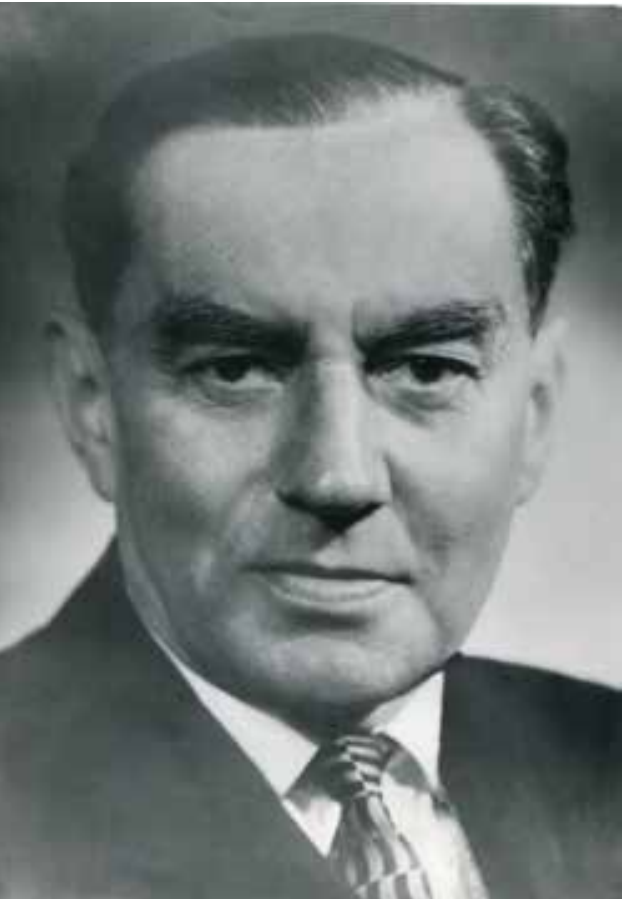

FIGURE 14 Prof. Leon

K. Gliński. Source:

Tygodnik llustrowany

(The Illustrated Weekly).

1918; 27-28: 313

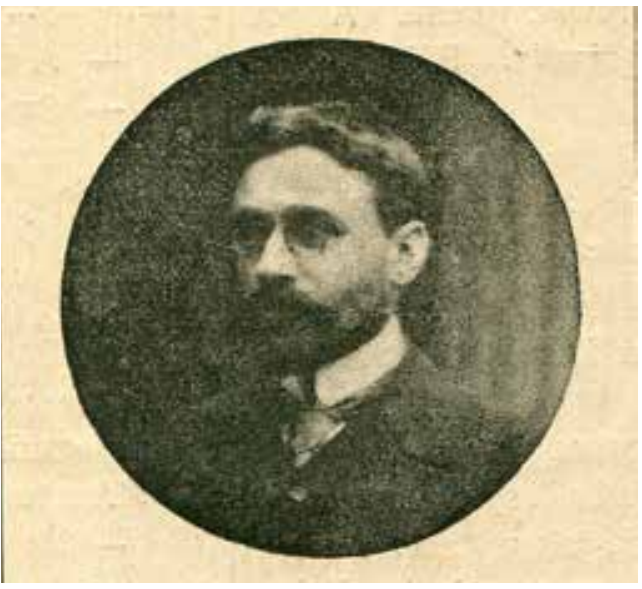

name is permanently imprinted in the beginnings of the world of brain neurophysiology. In 1889, when he was a young assistant in professor $\mathrm{Cy}$ bulski's Physiology Institute, he undertook, under Cybulski's influence, research on electrophysiological phenomena occurring in animal brains. Only a year later, he published the results of his experimental inquiry ${ }^{68,69}$ He used quite simple equipment of clay electrodes and a string galvanometer to record all the required data. Beck carefully described the localization of sensory modalities on the surface of the cerebral cortex, which could be observed on the grounds of electrical and sensory stimulation. The researcher found clear evidence that under stimulation, some parts of the cortex reactions were electronegative and that it was visible for several sensory modalities. $\mathrm{He}$ was also able to confirm the existence of spontaneous oscillations of brain potentials, which were not by any means related to physiologic changing actions of the heart and breathing. Of great importance was the statement that the change in the potentials must be connected with sensory stimulation. Beck should therefore be regarded as a pioneer in the field of research concerning the neurophysiological function of the cerebral cortex with description of the desynchronization mechanism triggered by stimulation which was visible on the electroencephalogram. ${ }^{66,67,70}$

Jan Miodoński (1902-1963), the president of the Cracow Doctors' Association in 1947-1948 In the years 1920-1926, Jan Miodoński (Figure 13) completed his studies at the Department of Medicine at Jagiellonian University. After graduation, he became an assistant in the Department of Otolaryngology at Jagiellonian University. In 1934, he presented his habilitation thesis and took lead of the department. In 1937, the scientist became an assistant professor, and in 1947 a full professor. He died in September 1963..$^{71,72}$

The range of Miodoński's research interests included otology, audiology, laryngology, and the physiology and pathophysiology of the hearing organ. At the beginning of 1930, while simultaneously conducting clinical and experimental research, Miodoński established galvanic tests for bony labyrinth, indicating that galvanic tests are more than useful in otoneurologic diagnostics. He was an author of selenoid theory of the fenestra novovalis, cochlea oscillation during sound osteoconductivity, and he also completed the image of mechanics of sound transmitting through ossicles. In addition, he had significant achievements in the field of surgery. Miodonski conducted the procedure of radical laryngectomy with glottis reconstruction, and recreation of physiological functions of speaking, breathing, and swallowing. He was an author of the tympanoplasty method, restoring hearing lost as the result of chronic middle ear infection. ${ }^{71,72}$

Leon Konrad Gliński (1870-1918), vice president of the Cracow Doctors' Association Leon K. Gliński (FIGURE 14) started his medical studies in Warsaw and then continued them in Kraków. In 1898, he was awarded the degree of doctor of medical sciences, and a year later he became an assistant at the Institute of Pathological Anatomy of Jagiellonian University. In 1904, he presented his habilitation thesis. He completed his complementary studies in Paris. In 1909, he became an assistant professor and in 1917 a full professor. He died in the summer of $1918 . .^{73,74}$

Gliński was a pioneer in the research on degenerative processes of the pituitary gland in their close relation to regulation and secretory gland disorders. In his publications from 1911 and 1913, he indicated the connection between the gland's frontal lobe with functions of reproductive glands. ${ }^{75-77}$ The researcher was the first one to describe the morphological changes of the gland during pregnancy and investigated its influence on pregnancy itself and on puerperium. He was an author of a detailed description of two cases of gland necrosis in cases of women giving birth. Gliński published a histopathological picture of necrotic changes indicating that clots and 
FIGURE 15

Prof. Ksawery

Lewkowicz, c 1910.

Photo. Kuczyński \&

Gürtler. Source:

Department of the

History of Medicine,

Jagiellonian University

Medical College, Kraków,

Poland

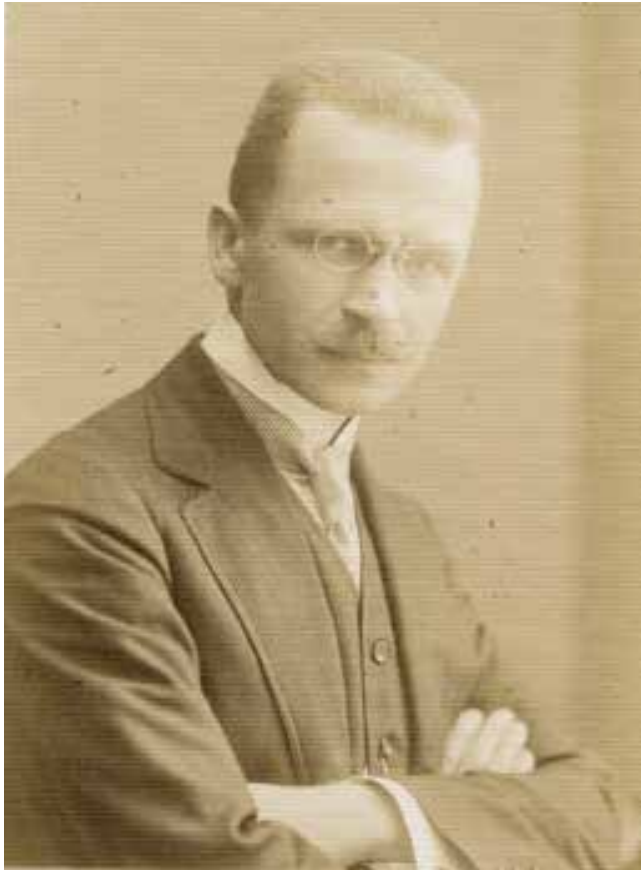

embolisms developed in the arterial twigs were a significant source of disease development. He pointed out that dysfunction of the glandular part of the gland causes disorders in the menstruation cycle, a decrease and often loss of sexual drive, and atrophy of secondary and tertiary sexual characteristics. Therefore, Gliński gave the picture of crucial characteristics of cachexia connected with damage and degeneration of the gland's frontal lobe. He named it with the original name of hypopituitarismus. Gliński's discovery was ahead of a similar publication by the German pathologist, Morris Simmonds, which was published in 1914. The German scientist's name was preserved in European medicine in the name Simmonds' disease. Truthfully, it should be named Gliński-Simmonds' disease. ${ }^{78}$

Ksawery Lewkowicz (1869-1958), member of the Cracow Doctors' Association Ksawery Lewkowicz (FIGURE 15) started his medical studies at Jagiellonian University in 1888. Because Lewkowicz was interested in pediatrics, he completed his complementary studies in Paris and then in Vienna. In 1895, he was awarded the degree of doctor of medical sciences. Two years later, he became an assistant at the Department of Children Diseases at Jagiellonian University. After habilitation in 1903, he became an associate professor, and four years later he was awarded the degree of assistant professor. At the same time, he took lead of the Department of Pediatrics at Jagiellonian University. In 1920, he became a full professor. ${ }^{79,80}$

Lewkowicz was engaged in rheumatology, neurology, and childhood infectious diseases. He was looking for new methods of diagnostics, therapy, and prophylaxis for children suffering from malaria, scarlet fever, tuberculosis, and meningitis. Lewkowicz was the first to culture the anaerobic mycobacterium Bacillus fusiformis, living in the mouth of infants and causing Plaut-Vincent angina, in a pure state. ${ }^{81}$ During his long-term studies on tuberculosis, Lewkowicz presented a full theory of tuberculo-rheumatic disease. According to his theory, erythema nodosum should be considered a basic, mild presentation of the disease course. The developed presentation is sepsis with a characteristic high level of immunization. He recognized distinctive caseous necrosis as characteristic image, connected with the weakening of the phagocyte system as a result of recurrent infections and a decrease in immunity in lung tissue. Lewkowicz considered isolated changes typical for rheumatism a relatively rare clinical picture of the disease. ${ }^{82-84}$

\section{REFERENCES}

1 Rybakowa M, Gajda Z, Czepko M. [Cracow Doctors' Association the past and the present. $135^{\text {th }}$ Anniversary]. Pamiętnik Towarzystwa Lekarskiego Warszawskiego. 2002; 88: 200-208. Polish.

2 Nowakowska-Zamachowska M. [The Introduction]. In: [Cracow Doctor's Association 1866-1914. Balneology Commission. The Doctoral Thesis.] Kraków; 2008: 4-7. http://dl.cm-uj.krakow.pl:8080/Content/1034/Doktorat_ monika-0802120k.pdf. Polish.

3 Ziejka F. [Cracow Doctors' Association permanently imprinted in the history of Kraków]. In: Wiernikowski A, ed. [Cracow Doctor's Association. 150 Anniversary (1866-2016)]. Kraków: Towarzystwo Lekarskie Krakowskie \& Okręgowa Izba Lekarska w Krakowie; 2016; 29-66. Polish.

4 Ściborowski W. [A few words about the establishing and the hitherto activities of Cracow Doctors' Association]. Przegl Lek. 1866; 5: 374. Polish.

5 Giędosz B. [A few words about Cracow Doctors' Association in the past]. Przegl Lek.1966; 22: 666-667. Polish.

6 Schmidt-Pospuła M. [Medical Review-the History of Origin and its Beginnings]. In: Gościński I, Skotnicki AB, eds. [Cracow Doctors' Association. The Jubilee Book]. Kraków: Krakowskie Towarzystwo Edukacyjne. Oficyna Wydawnicza AFM; 2006. Polish.

7 Sułowicz W, Gościński I, Wiernikowski A. [The Publishing Activity of Cracow Doctors' Association]. In: Wiernikowski A, ed. [Cracow Doctors' Association. 150 th Anniversary (1866-2016)]. Kraków: Towarzystwo Lekarskie Krakowskie \& Okręgowa Izba Lekarska w Krakowie; 2016: 105-109. Polish.

8 Madurowicz M. [Meeting of Cracow Doctors' Association from the date of $4^{\text {th }}$ of December 1889]. Przegl Lek. 1890; 29: 667-672. Polish.

9 Zamachowska M. [The Relations between Doctors' Association and Medical Department]. In: Gościński I, Skotnicki AB, eds. [Cracow Doctors' Association. The Jubilee Book]. Kraków, Krakowskie Towarzystwo Edukacyjne. Oficyna Wydawnicza AFM. 2006: 23-29. Polish.

10 Giędosz B, Hałuszka J, Rokicki W. [Cracow Doctors' Association and the health state in the city of Kraków]. Przegl Lek. 1967; 22: 358-361. Polish.

11 Romanowska M. Stanisław Wyspiański 1869-1907. [The House of Doctors' Association and other interiors from 1904]. In: Gościński I, Skotnicki AB, eds. [Cracow Doctors' Association. The Jubilee Book]. Kraków: Krakowskie Towarzystwo Edukacyjne. Oficyna Wydawnicza AFM; 2006: 43-54. Polish.

12 Beiersdorf Z. [The Doctors' House - the seat of Cracow Doctors' Association as a work of art]. In: Gościński I, Skotnicki AB, eds. [Cracow Doctors' Association. The Jubilee Book]. Kraków, Krakowskie Towarzystwo Edukacyjne. Oficyna Wydawnicza AFM; 2006: 55-133. Polish.

13 Giędosz B. 0 towarzystwach lekarskich [About medical associations]. Przegl Lek. 1966; 22: 667-672. Polish.

14 Skulimowski M. [The Outline of history of Cracow Doctor's' Association and Department of Polish Medical Association in Kraków (1866-1966)]. Przegl Lek. 1967; 22: 362-366. Polish.

15 Gościński I, Wiernikowski A, Zawiliński J. [Cracow Doctors' Association - the past and the present]. In: Wiernikowski A, ed. [Cracow Doctors Association. 150 th Anniversary (1866-2016)]. Kraków: Towarzystwo Lekarskie Krakowskie \& Okreggowa lzba Lekarska w Krakowie; 2016: 75-87. Polish 16 Wachholz L, Biesiadecki Alfred. In: [Polish Biographical Dictionary] Kraków: PAU. 1936: 87-88. Polish.

17 Pagel J. Biographisches Lexikon hervorragender Ärzte des neunzehnten Jahrhunderts. Mit einer historischen Einleitung. Berlin-Wien: Urban \& Schwarzenberg; 1901: 171. German

18 Scheuthauser G. Biesiadecki Alfred. In: Biographisches Lexikon de hervorragenden Ärzte aller Zeiten und Völker. August Hirsch, ed. München-Berlin: Urban \& Schwarzenberg; 1962: 532. German.

19 Dańczura-Dynowska J. [Alfred Biesiadecki, an outstanding Polish his topathologist and his input to dermatology]. Arch Hist Filoz Med. 1995; 58 379-396. Polish. 
20 Ciechanowski S. Browicz Tadeusz. In: [Polish Biographical Dictionary] Kraków: PAU; 1936: 475-476. Polish.

21 Śródka A. Browicz Tadeusz. In: Śródka A, ed. [Polish scientists of $19^{\text {th }}$ and 20 ${ }^{\text {th }}$ century]. Warszawa: Aries; 1994: 208-210. Polish.

22 Hanecki M. [Life and scientific activities of Tadeusz Browicz]. Warszawa: PZWL; 1956. Polish.

23 Stachura J, Gałąza K. History and current status of Polish gastroenterological pathology. J Physiol Pharmacol. 2003; 54 (Suppl 3): 183-192.

24 Śródka A, Gryglewski RW, Szczepański W. Browicz or Kupffer cells? Pol J Pharmacol. 2006; 57: 183-185.

25 Aleksandrowicz J, Lisiewicz J, Korczyński Edward. In: [Polish Biographical Dictionary]. Kraków: Ossolineum; 1968-1969: 49-51. Polish.

26 Zwolski S. Edward Sas Korczyński (1844-1905). In: Skalski JH, Gryglewski RW, eds. [Distinguished in their services to medicine Europeans from the Polish soil]. Poznań: Termedia; 2009: 137-144. Polish

27 Korczyński E. [Coronary arterial embolism of the heart diagnosed during the lifetime]. Przegl Lek. 1887; 26: 20-21, 41-43, 57-59, 75-76. Polish.

28 Skalski JH. [Heart attack and angina pectoris in the history of Polish medicine. Part 2. Diagnosis and the beginnings of treatment $-19^{\text {th }}$ and $20^{\text {th }}$ century]. Pol Arch Med Wewn. 2008; 118: 248-254. Polish.

29 Kozuschek W. [Jan Mikulicz-Radecki 1850-1905.The co-founde of modern surgery]. Wrocław, Poland: Wydawnictwo Uniwersytetu Wrocławskiego; 2005. Polish.

30 Mikulicz J. Ueber Gastroskopie und Oesophagoskopie. Wiener med izinische Presse 1881, 22. 1405-1408, 1437-1443, 1473-1475, 1505-1507, 1537-1541, 1573-1577, 1629-1631. German.

31 Brauer L, Petersen W. Über eine wesentliche Vereinfachung der künstlichen Atmung nach Sauerbruch. Zeitschrift für Physiologische Chemie. 1904; 41: 299-302. German.

32 Sauerbruch F. Über die Ausschaltung der schädlichen Wirkung de Pneumothorax bei intrathorakalen Operationen. Zentralbl Chir. 1904; 31 146-149. German

33 Śródka A. Gluziński Antoni. In: Śródka A, ed. [Polish scientists of $19^{\text {th }}$ and $20^{\text {th }}$ century]. Warszawa: Aries; 1994: 529-531. Polish.

34 Śródka A. Antoni Gluziński - A classic of Polish internal medicine. Organon. 2004; 33: 159-168.

35 Kucharz EJ. [Władysław Antoni Gluziński - an eminent Polish internist, founder of the Polish Society of Internal Medicine.] Pol Arch Med Wewn. 2007; 117: 270-273. Polish.

36 Paciorkiewicz M. [The 40th anniversary of Prof. Antoni Gluziński's death (1856-1935).] Arch Hist Filoz Med. 1975; 38: 375-381. Polish.

37 Gluzinski A, Reichenstein M. Myeloma und Leucaemia lymphatica plasmocellularis. Wien Klin. Wochenschr. 1906; 19: 336-339. German.

38 Śródka A. Kostanecki Kazimierz. In: Śródka A, ed. [Polish scientists of $19^{\text {th }}$ and $20^{\text {th }}$ century]. Warszawa: Aries; 1994: 285-288. Polish.

39 Kohmann S. Kazimierz Kostanecki (1863-1940). In: 600th anniversary of medicine in Kraków. Kraków, Poland: Akademia Medyczna w Krakowie; 1963: 283-310. Polish.

40 Pagel J. Biographisches Lexikon hervorragender Ärzte des neunzehnten Jahrhunderts. Mit einer historischen Einleitung. Berlin-Wiedeń: Urban \& Schwarzenberg; 1901: 904-905. German

41 Sokołowska-Pituchowa J. 400 Years of the Chair of Anatomy in Kraków (1602-2002). Kraków: Wydawnictwo UJ; 2002: 36-37: 104-105. Polish.

42 Kostanecki K. Cytologische Studien an künstlich parthenogenetisch sich entwickelnden Eiern von Mactra. Archive für mikroscopische Anatomie. 1904: 64:1-98. German.

43 Kostanecki K. Zur Morphologie der künstlichen parthenogenetischen Entwicklung bei Mactra. Archive für mikroscopische Anatomie. 1908; 72 327-352. German

44 Kostanecki K. Le caecum des vertébrés (y compris I"appendice vermic ulaire"): morphologie et signification fonctionnelle. Bulletin International de I'Academie des Sciences de Cracovie, Classe des sciences mathématiques et naturelles.1926; Ser. B, spl: 1-295. French.

45 Śródka A. Nowak Julian. In: Śródka A, ed. [Polish scientists of $19^{\text {th }}$ and $20^{\text {th }}$ century]. Warszawa: Aries; 1997: 258-260. Polish.

46 Nowakowska-Zamachowska M, Gryglewski RW. [Julian Ignacy Nowak - between the medicine and the politics]. Med Weter. 2014; 70: 443-447. Polish.

47 Śródka A. Cybulski Napoleon. In: Śródka A, ed. [Polish scientists of 19 and $20^{\text {th }}$ century]. Warszawa: Aries; 1994: 292-295. Polish.

48 Gryglewski RW. Napoleon Nikodem Cybulski (1854-1919). In: Skalski $\mathrm{JH}$, Gryglewski RW, eds. [Distinguished in their services to medicine Europeans from the Polish soil]. Poznań: Termedia; 2009: 202-207. Polish.

49 Pawlik W, Konturek S, Bilski R. Napoleon Cybulski - Polish pioneer in developing of the device for measuring blood flow velocity. J Physiol Pharmacol. 2006; 57 (Suppl 1): 107-118.

50 Szymonowicz L. Die Function der Nebenniere. Archiv für die gesamte Physiologie des Menschen und Tiere. 1895; 64: 97-164. German.

51 Gryglewski RW. Kader-Kadaras Bronisław. In: Orłowski B, ed. [The Polish input in natural sciences and technology. The Dictionary of discoverers, intors and pioneers of mathematical-natural sciences and technology from Poland and with Polish background]. Warszawa: Instytut Historii Nauki im. L.iA. Birkenmajerów PAN, Instytut Pamięci Narodowej; 2015: 152-153. Polish.

52 Magowska A. Surgery, fame, and misfortune: the life of Bronistaw Kader. World J Surg. 2012; 36: 1998-2002.

53 Kader B. Ein experimenteller Beitrag zur Frage des lokalen Meteorismus bei Darmokklusion. Inaug-Diss. Dorpat 1891. German.

54 Witzel 0. Zur technik der magenfistulaeinlegung. Zentralbl Chir. 1891 18: 601-604. German

55 Kader B. Zur technik der gastrostomie. Zentralbl Chir. 1896: 23 665-670. German.

56 Brzezicki E. Jan Piltz. Arch Psychiatr Nervenkr. 1931; 95: 1-7.

57 Chłopicki W. [Biography and activity of the late Professor Jan Piltz]. Nowiny Psychjatryczne. 1931; 8: 1-15. Polish.

58 Magowska A. Jan Piltz (1870-1930). J Neurol. 2015; 262: 1099-1100.

59 Gościnski I. Jan Władysław Piltz (1870-1930). In: Grochowski J. [Golden Book of Medical Faculty UJ]. Kraków, Poland: Księgarnia Akademicka 2000: 377-382. Polish

60 Westphal AK. Ueber ein bisher nicht beschriebenes Pupillephaenomen. Neurologisches Zentralblatt. 1899; 18: 161-164. German.

61 Piltz J. [ About new papillary fenomenons]. Gazeta Lekarska. 1899; 34 928-935. Polish.

62 Gryglewski RW. Aleksander Rosner (1867-1930). In: Kozub-Ciembroniewicz W, ed. Academics of Jewish Heritage in the Modern History of The Jagiellonian University. Kraków: Jagiellonian University Press; 2014: 227-234.

63 Szarejko P. Rosner Aleksander. In: [Polish Biographical Dictionary]. Wrocław-Warszawa-Kraków: Ossolineum; 1989-1991: 104-105. Polish.

64 Rosner A. [Studies in the construction of woman's sexual organs] Rozprawy Wydziału Matematyczno-Przyrodniczego AU, Kraków. 1918; 18 : 55-114. Polish.

65 Rosner A. [The myoma of the uterus and their location in the light of knowledge on constitiuon of woman's sexual organs]. Przegl Lek. 1920; 59 65-69. Polish.

66 Zayachkivska 0, Gzhegotsky M, Coenen A. Impact on electroencephalography of Adolf Beck, a prominent Polish scientist and founder of the Lviv School of Physiology. Int J Psychophysiol. 2012; 85: 3-6.

67 Pietrzak K, Grzybowski A, Kaczmarczyk J. Adolf Beck (1863-1942) A Pioneer of Electroencephalography. Eur Neurol. 2014; 71: 32-34.

68 Beck A. Die Bestimmung der Localisation der Gehirn- und Rückenmarksfunctionen vermittelst der electrischen Erscheinungen. Centralblatt für Physiologie. 1890; 4: 473-476. German.

69 Beck A. [Localization assessment in the brain and the spinal cord using electrical phenomena] Rozprawy Wydziału Matemetyczno-Przyrodniczego AU, Kraków. 1890; 21: 186-232. Polish.

70 Coenen A, Zayachkivska 0. Adolf Beck: A pioneer in electroencephalography in between Richard Caton and Hans Berger. Adv Cogn Psychol. 2013; 9: 216-221.

71 Kowal E. [Currentness of Jan Miodoński's pioneering ideas in Otolaryngology]. Kraków: Collegium Medicum UJ; 1995. Polish.

72 Śródka A. Miodoński Jan. In: Śródka A, ed. [Polish scientists of $19^{\text {th }}$ and $20^{\text {th }}$ century]. Warszawa, Poland: Aries; 1995: 150-152. Polish.

73 Jeszke W. [Leon Konrad Gliński (1870-1918) professor of the patholog ical anatomy of the Jagellonian University in Cracow.] Arch Hist Med. 1968 31: 255-264. Polish.

74 Zembrzuski L, Wrzosek A. [The Contribution to Professor Leon Konrad Gliński's Biography]. Przegl Lek. 1960; 16: 29-30. Polish.

75 Gliński LK. [About pituitary gland]. In [The Memorial Book of $11^{\text {th }}$ Convention of Polish Doctors and Natural Scientists in Kraków]. Komitet Gospodarczy, Kraków; 1911: 411. Polish.

76 Gliński LK. [From the casuistry of anatomopathological changes in the pituitary gland]. Przegl Lek. 1913; 52: 13-14. Polish

77 Gliński LK. Anatomische Veränderungen der Hypophyse. Dtsch Med Wochenschr. 1913; 39: 473. German.

78 Robertson JD. Glinski and the aetiology of Simmonds's disease. BMJ. 1951; 1: 921-923.

79 Śródka A. Lewkowicz Ksawery. In: Śródka A, ed. [Polish scientists of $19^{\text {th }}$ and $20^{\text {th }}$ century]. Warszawa, Poland: Aries; 1995: 501-502. Polish.

80 Marzec M. [Ksawery Lewkowicz (1869-1958) - an outstanding pediatrist and bacteriologist]. Wiad Lek. 1982; 35: 845-847. Polish.

81 Lewkowicz K. [Pure culture of Bacillus fusiformis]. Rozprawy Wydziału Matematyczno-przyrodniczego AU, Kraków. 1906; Ser III B, 5: 469-477. Polish

82 Lewkowicz K. [Tuberculosis among children]. Przegl Lek. 1910; 49 49-52. Polish.

83 Lewkowicz K. [The tuberculo-rhematic disease]. Przegl Lek. 1945; 1 49-53, 78-84, 110-115, 139-145. Polish.

84 Lewkowicz K. Essential notions on tuberculo-rheumatic disease. Acta Paediatr. 1948; 36: 401-403 